\title{
Anti-diabetic effect of Momordicacharantia plant extract in Streptozotocin induced diabetic mice
}

\author{
NAYYAB SULTAN ${ }^{1}$, ZAHID HUSSAIN, SABAHATJAVAID BUTT, AQIB JAVAID BUTT \\ Institute of Industrial Biotechnology, Government College University, Lahore, Affiliated to Higher Education Commision, Islamabad, Pakistan \\ Correspondence to Ms Nayyab Sultan Email: nayyabsultan041@gmail.com, +923214235711
}

\begin{abstract}
This study describes anti-hyperglycemic effect of Momordicacharantia extract commonly known as bitter melon. Random blood glucose levels were observed before and after plant extract administration. Powdered form of plant extract was used as an oral treatment. Diabetes was induced in animal (mice) models by using streptozotcin which is an artificial diabetes inducer. Maximum anti-hyperglycemic effect and blood glucose level reduction was observed in individual treatment of Momordicacharantiaextract $(500 \mathrm{mg} / \mathrm{kg})$ which was $75 \% \pm 1.3$. This treatment was more effective as compared to Amaryl $(3 \mathrm{mg} / \mathrm{kg})$ which shows effectiveness of $52 \% \pm 2.4$ and Glucophage $(500 \mathrm{mg} / \mathrm{kg})$ which shows effectiveness of $29 \% \pm 2.1$. Results indicate that bitter melon contain antihyperglycemic proteins which are helpful in diabetes treatment without any toxic side effects. Still more research, experiments and testing needs to be perform.
\end{abstract}

Keywords: Amaryl; Anti-hyperglycemic effect; Blood glucose levels; Body weight; Diabetes mellitus

\section{INTRODUCTION}

Momordicacharantiais a herb which is widely cultivated through-out different regions of the world. It is used as vegetable. It is not only used as food but also contain pharmaceutical properties. Its fruit contain different medicinal effects as anti-hyperglycemic ${ }^{21}$, anti-diabetic, anti-fungal ${ }^{3}$, anti-oxidant, cytotoxic activity ${ }^{32}$ and inhibition against tyrosine ${ }^{31}$. It is reported that Momordicacharantia extract had anti-hyperglycemic effect in diabetic mice ${ }^{30}$.

Diabetes mellitus is considered as most serious disorder having severe impact on health and quality of life expectancy within patients and on health associated system. It is a chronic disorder mainly grouped as type 1 diabetes mellitus and type 2 diabetes mellitus. Type 1 is due to insulin deficiency and type 2 is due to insulin resistance. For the treatment of this disease, different oral synthetic drugs and insulin are available in market.

Insulin shows low side effects as compared to synthetic drugs which show serious effects and toxicity. Insulin is not available in its oral form. Synthetic and artificial drugs are available for oral administration. So, we are in a strict need for effective and safe agents in order to continue our important portion of an active research. We must grow our interest towards identifying anti-diabetic and natural products in order to treat diabetes.

\section{MATERIALS AND METHODS}

Preparation of Momordicacharantia extract: Momordicacharantia plant was taken in its raw form and dried its distributed portion in drying oven. It was placed for about one week at $60^{\circ} \mathrm{C}$. After obtaining dried form of the required plant, it was converted into powdered form by crushing mechanically or by grinding in a grinder. Greenish yellow powder was obtained and used for practical. Remaining amount was stored in eppendorf tubes at $25^{\circ} \mathrm{C}$ for further experimental procedures.

Received on 23-02-2021

Accepted on 17-06-2021
Experimental animals: Male albino mice were used having age of about three months. Their weight was in a range of 20-25 g. One group was selected as a control group and other group was selected as an experimental group. They were kept under observation for few days in order to make them suitable towards new environement. During observation, their behavioral changes were also noticd. In summer, room temperature was maintained at $35-37^{\circ} \mathrm{C}$ and during winter, temperature was maintained at $42-43^{\circ} \mathrm{C}$. Day light and night exposure was also maintained. Commercial feed was provided throughout whole research.

\section{Diabetes induction in mouse}

$0.05 \mathrm{M}$ sodium citrate buffer preparation (pH 4.5): Sodium citrate stock solution was prepared by adding 1.2 $\mathrm{g}$ sodium citrate and $1.1 \mathrm{~g}$ citic acid in some amount of distilled water. Raise the volume up to $100 \mathrm{ml}$ by adding distilled water. This is $0.1 \mathrm{M}$ concentration of stock solution. In order to prepare $0.05 \mathrm{M}$ concentartion, mix 50 $\mathrm{ml}$ of stock solution with $50 \mathrm{ml}$ of distilled water. Adjust $\mathrm{pH}$ to 4.5. This solution must be prepared fresh and placed in ice before inducing diabetes.

Streptozotocin-sodium citrate buffer preparation: Streptozotocin was dissolved in buffer. Three low doses (40 mg/kg) were administered for three days and two low doses $(50 \mathrm{mg} / \mathrm{kg}$ ) were provided intraperitoneally for two days. Restainers can be used for mice handling. Scruffing is a technique which can also be used for handling mice. Streptozotocin and buffer were mixed immediately before injecting because buffer degrades STZ within minures. Blood glucose levels were measured after $72 \mathrm{~h}$ of buffer injection.

STZ per mouse

STZ $(40 \mathrm{mg} / \mathrm{kg}): \frac{20}{1000} \times 40=0.0008 \mathrm{~g}($ Table 1$)$

STZ $(50 \mathrm{mg} / \mathrm{kg}): \frac{20}{1000} \times 50=0.001 \mathrm{~g}($ Table 1$)$

Table 1: STZ-Na citrate dose

\begin{tabular}{|l|c|c|}
\hline $\begin{array}{l}\text { Streptozotocin } \\
\text { dose }(\mathbf{m g} / \mathbf{k g})\end{array}$ & $\begin{array}{c}\text { Mouse weight } \\
(\mathbf{g})\end{array}$ & STZ-Na citrate dose \\
\hline $40 \mathrm{mg} / \mathrm{kg}$ & $20 \mathrm{~g}$ & $0.0008 \mathrm{~g} \mathrm{STZ}+0.3 \mathrm{ml}$ buffer \\
\hline $50 \mathrm{mg} / \mathrm{kg}$ & $20 \mathrm{~g}$ & $0.001 \mathrm{~g} \mathrm{STZ}+0.3 \mathrm{ml}$ buffer \\
\hline
\end{tabular}


Table 2: Experimental design

\begin{tabular}{|l|l|}
\hline Groups & \multicolumn{1}{c|}{ Treatment } \\
\hline Negative control & Non-diabetic and untreated group \\
\hline Positive control & Diabetic and untreated group \\
\hline Group 1 & $\begin{array}{l}\text { Administration of Momordicacharantiaextract in } \\
\text { diabetic mice }\end{array}$ \\
\hline Group 2 & Administration of Amaryl in diabetic mice \\
\hline Group 3 & Administration of Glucophage in diabetic mice \\
\hline
\end{tabular}

\section{Administration of treatments}

Administration of Momordicacharantiaextract (Table

2): $\quad$ Plant extract was prepared by adding Momordicacharantia powder (500 mg/kg dose) in $0.2 \mathrm{ml}$ of distilled water. Assure homogenous mixing by using a vortex mixer. This prepared solution was administered orally for one week. Mice can be handled by using restrainer technique or by scruffing. Blood glucose level was monitored before and after treatment (Table 3).

Dose calculation formula $=\frac{\text { weight }(\mathrm{g})}{1000} \times \frac{500 \mathrm{mg}}{1000}$

Administration of Amaryl: Amaryl is a synthetic drug used by diabetic patients. Medicinal extract was prepared by adding Amaryl powder ( $3 \mathrm{mg} / \mathrm{kg}$ dose) in $0.1 \mathrm{ml}$ of distilled water. Assure homogenous mixing by using a vortex mixer. This prepared solution was administered orally for one week. Mice can be handled by using restrainer technique or by scruffing. Blood glucose level was monitored before and after treatment (Table 4).
Dose calculation formula $=\frac{\text { weight }(\mathrm{g})}{1000} \times \frac{3 \mathrm{mg}}{1000}$

Administration of Glucophage: Glucophage is a synthetic drug used to treat diabetes. Medicinal extract was prepared by adding Glucophage powder $(500 \mathrm{mg} / \mathrm{kg}$ dose) in $0.2 \mathrm{ml}$ of distilled water. Assure homogenous mixing by using a vortex mixer. This prepared solution was administered orally for one week. Mice can be handled by using restrainer technique or by scruffing. Blood glucose level was monitored before and after treatment (Table 5).

Dose calculation formula $=\frac{\text { weight }(\mathrm{g})}{1000} \times \frac{500 \mathrm{mg}}{1000}$

Estimation of glucose levels: Testing glucometer was used for the estimation of blood glucose levels of each mouse before and after treatments. Glucose level crossing barrier of $150 \mathrm{mg} / \mathrm{dl}$ is considered diabetic.

Statistical analysis: SPSS was used to perform the statistical analysis of different conditions. Paired t-test was conducted in order to calculate the significance of each result obtained. ANOVA (Analysis of Variance) was also applied and data was statistically analyzed. P-value is obtained in this case. This is the value of significance showing the quality of results obtained. It is denoted by alpha $(\alpha)$. If the value of alpha is less than 0.05 , then the results are considered significant.

\section{RESULTS}

$$
\begin{gathered}
\text { Reduced } \mathrm{BGLs}=(\text { BGLs after STZ }- \text { Control })-(\text { BGLs after treatment }- \text { Control }) \\
\% \text { reduction in BGLs }=\frac{\text { Reduced BGLs }}{\text { BGLs after STZ }- \text { Control }} \times 100
\end{gathered}
$$

\begin{tabular}{|c|c|c|c|c|c|c|}
\hline (Group 1) & \multicolumn{4}{|c|}{ Glucose level (mg/dl) } & \multirow{2}{*}{$\begin{array}{c}\% \text { Decrease in } \\
\text { BGLs }\end{array}$} & \multirow{2}{*}{$\begin{array}{l}\text { Treatment effect } \\
\text { remain for days }\end{array}$} \\
\hline Mice No. & -Ve Control & + Ve Control & After STZ & After MC extract treatment & & \\
\hline 1 & 97 & 290 & 300 & 150 & $74 \%$ & 18 \\
\hline 2 & 90 & 328 & 353 & 120 & $89 \%$ & 21 \\
\hline 3 & 72 & 300 & 312 & 160 & $63 \%$ & 15 \\
\hline 4 & 89 & 250 & 306 & 122 & $85 \%$ & 11 \\
\hline 5 & 91 & 300 & 340 & 180 & $64 \%$ & 20 \\
\hline
\end{tabular}

Table 3: Effect of Momordicacharantiaplant extract $(500 \mathrm{mg} / \mathrm{kg})$ in diabetic mice

Standard mean of percentage reduction in blood glucose levels came out to be $75 \% \pm 1.3$.

\begin{tabular}{|c|c|c|c|c|c|c|}
\hline (Group 2) & \multicolumn{4}{|c|}{ Glucose level (mg/dl) } & \multirow{2}{*}{$\begin{array}{c}\% \text { Decrease in } \\
\text { BGLs }\end{array}$} & \multirow{2}{*}{$\begin{array}{l}\text { Treatment effect } \\
\text { remain for days }\end{array}$} \\
\hline Mice No. & -Ve Control & +Ve Control & After STZ & After Amaryl treatment & & \\
\hline 1 & 92 & 315 & 325 & 209 & $50 \%$ & 03 \\
\hline 2 & 71 & 361 & 341 & 230 & $41 \%$ & 05 \\
\hline 3 & 102 & 322 & 300 & 200 & $51 \%$ & 02 \\
\hline 4 & 97 & 291 & 324 & 190 & $59 \%$ & 04 \\
\hline 5 & 90 & 300 & 320 & 182 & $60 \%$ & 07 \\
\hline
\end{tabular}

Table 4: Effect of Amaryl (3mg/kg) in diabetic mice

Standard mean of percentage reduction in blood glucose levels came out to be $52 \% \pm 2.4$.

Table 5: Effect of Glucophage $(500 \mathrm{mg} / \mathrm{kg})$ in diabetic mice

\begin{tabular}{|c|l|l|l|l|l|l|}
\hline (Group 3) & \multicolumn{2}{|c|}{ Glucose level (mg/dl) } & \% Decrease in & $\begin{array}{c}\text { Treatment effect } \\
\text { remain for days }\end{array}$ \\
\hline Mice No. & -Ve Control & +Ve Control & After STZ & After Glucophage treatment & & 02 \\
\hline 1 & 84 & 349 & 362 & 300 & $22 \%$ & 07 \\
\hline $\mathbf{2}$ & $\mathbf{9 0}$ & $\mathbf{3 0 0}$ & $\mathbf{3 2 0}$ & $\mathbf{2 3 0}$ & $\mathbf{3 9 \%}$ & \\
\hline 3 & 93 & 371 & 328 & 248 & $34 \%$ & 03 \\
\hline 4 & 106 & 291 & 315 & 270 & $22 \%$ & 05 \\
\hline 5 & 73 & 322 & 309 & 240 & $29 \%$ & 02 \\
\hline
\end{tabular}

Standard mean of percentage reduction in blood glucose levels came out to be $29 \% \pm 2.1$.

Comparing results of Momordicacharantiaplant extract, Amaryl and Glucophage 
Fig. 1: Comparison among best treatments in diabetic mice

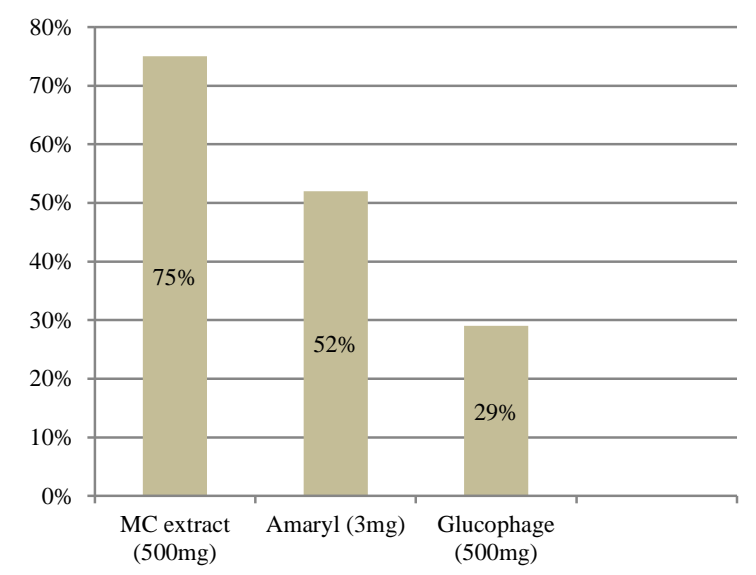

\section{DISCUSSION}

Diabetes mellitus is linked with different changes in carbohydrates, proteins and lipids profile with increased rate of heart problems ${ }^{4}$. Liver and tissues are involved in metabolic conversion of different components. Most of the plants and herbs contain specific products which are helpful in overcoming diseases and related complications ${ }^{5}$. Momordicacharantia plant is one of them showing antihyperglycemic properties ${ }^{17}$. It is studied that treatment of streptozotocin induced diabetic mice with Momordicacharantia plant extract shows insulin like effect by lowering blood glucose levels and increasing insulin levels in plasma ${ }^{25}$.

Plant extract is also involved in partially reversing the hyperglycemic condition in STZ induced diabetic mice.It is helpful in improving the action and secretion of level of insulin in blood plasma. It is involved in the increased output of insulin from the pancreatic beta cells in diabetic animal models ${ }^{29}$. Plant extract not only mimics the activity of insulin but also shows synergistic effect on the performance of insulin. Increased production of beta cells was also reported after treating with karela extract ${ }^{2}$.

Maximum anti-hyperglycemic effect and blood glucose level reduction was observed in individual treatment of Momordicacharantiaextract $(500 \mathrm{mg} / \mathrm{kg})$ which was $75 \% \pm 1.3$. This treatment was more effective as compared to Amaryl $(3 \mathrm{mg} / \mathrm{kg})$ which shows effectiveness of $52 \% \pm 2.4$ and Glucophage $(500 \mathrm{mg} / \mathrm{kg})$ which shows effectiveness of $29 \% \pm 2.1$.

\section{CONCLUSION}

Results indicate that bitter melon contain antihyperglycemic proteins which are helpful in diabetes treatment without any toxic side effects. Still more research, experiments and testing needs to be perform.

Acknowledgement: We wish to thank Professor Dr Hamid Mukhtar, Institute of Industrial Biotechnology, Government College University, Lahore Pakistan, for their support and encouragement. We are also indebted to M. Atta-urRehman Bin Sultan, for taking care of the experimental animals and for helping us during statistical analysis.

Conflict of interest: Nil

\section{REFERENCES}

1. Abascal K, Yarnell E. Using Momordicacharantia to treat diabetes. J Altern Complement Med. 2005; 1:179-84.

2. Ahmed I., Adeghate E., Sharma A.K., PallotD.J. and Singh J. Effects of Momordicacharantia fruit juice on islet morphology in the pancreas of streptozotocin-diabetic rats, Diabetes Res. Clin. Pract. 40 (1998) 145-151.

3. Alam S., Asad M., Asdaq S.M.B. and Prasad V.S. Antiulcer activity of methanolic extract of Momordicacharantia L. in rats, J. Ethnopharmacol. 123 (2009) 464-469.

4. Betteridge J. Lipid disorders in diabetes mellitus, in: J.C. Pickup, G. Williams (Eds.), Text Book of Diabetes, second ed., Blackwell Science, London, 1997, p.p. 55.1-55.31.

5. Brown G.B., Xue-Qiao Z., Sacco D.E. and Alberts J.J. Lipid lowering and plaque regression. New insights into prevention of plaque disruption and clinical events in coronary disease, Circulation 87 (1993) 1781-1791.

6. Budrat P, Shotipruk A. Extraction of phenolic compounds from fruits of Momordicacharantia with subcritical water extraction and antioxidant activities of these extracts. Chiang Mai J Sci. 2008; 35(1):123-30.

7. Cefalu WT, Ye J, Wang ZQ. Efficacy of dietary supplementation with botanicals on carbohydrate metabolism in humans. EndocrMetab Immune Disord Drug Targets. 2008;8:78-81.

8. Cousens $G$. There is a cure for diabetes: the tree of life 21 day programs. California: North Atlantic Books. 2008:191-92.

9. da Rocha Fernandes J, Ogurtsova K, Linnenkamp U, Guariguata L, Seuring T, Zhang P, Cavan D, Makaroff LE. IDF Diabetes Atlas estimates of 2014 global health expenditures on diabetes. Diabetes Res Clin117. 2016:48-54.

10. Das SK, Elbein SC. The genetic basis of type 2 diabetes. J Cell Sci. 2006; 2(4):100.

11. Deeds M, Anderson J, Armstrong A, Gastineau D, Hiddinga $H$, Jahangir A, Eberhardt N, Kudva YC. Single dose streptozotocin-induced diabetes: considerations for study design in islet transplantation models. Lab Anim. 2011;45(3):131-40.

12. DeFronzo RA, Bonadonna RC, Ferrannini E. Pathogenesis of NIDDM: a balanced overview. Diabetes care. 1992;15(3):31868.

13. Esteban R. Management of chronic hepatitis B: an overview, paper presented by Thieme Medical Publishers, Inc., 333 Seventh Avenue. 2002.

14. Hebi M, Farid $O$, Ajebli M, Eddouks M. Potent antihyperglycemic and hypoglycemic effect of TamarixarticulataVahl in normal and streptozotocin-induced diabetic rats. Biomed Pharmacother. 2017;87:230-39.

15. Hemalatha S, Sachdeva N, Wahi A, Singh P, Chansouria J. Effect of aqueous extract of fruits of Withaniacoagulans on glucose utilization by rat hemidiaphragm. Ind $\mathrm{J}$ Nat Prod. 2005;21(2):20-21.

16. Hu FB. Globalization of diabetes: the role of diet, lifestyle and genes. Diabetes care. 2011;34(6):1249-57.

17. KarunanayakeE.H. and TennekoonK.H.Search of novel hypoglycaemic agents from medicinal plants, in: A.K. Sharma (Ed.), Diabetes Mellitus and Its Complications, An Update, Macmillan India Ltd, New Delhi, India, 1993, pp. 192-205.

18. Lo HC, Tu ST, Lin KC, Lin SC. The anti-hyperglycemic activity of the fruiting body of Cordyceps in diabetic rats induced by nicotinamide and streptozotocin. Life Sci. 2004;74(23):2897-908.

19. Mo R, Jiang T, Di J, Tai W, Gu Z. Emerging micro-and nanotechnology based synthetic approaches for insulin delivery. ChemSoc Rev. 2014;43(10):3595-629.

20. Naslafkih A, Sestier F. Diabetes mellitus related morbidity, risk of hospitalization and disability. J Insur Med. 2003;35(2):102-13. 
21. RaoB.K., KesavuluS.M.M. andApparaoC. Anti-hyperglycemic activity of Momordicacymbalaria in alloxan diabetic rats, $J$. Ethnopharmacol. 78 (2001) 7-71.

22. Ross SA, Gulve EA, Wang M. Chemistry and biochemistry of type 2 diabetes. Chem Rev. 2004;104(3):1255-82.

23. Saeed MK, Shahzadi I, Ahmad I, Ahmad R, Shahzad K, Ashraf M. Nutritional analysis and antioxidant activity of bitter gourd (Momordicacharantia) from Pakistan. Pharmacol. 2010; 1:252-60.

24. Shaheen TI, EI-Naggar ME, Hussein JS, El-Bana M, Emara E, El-Khayat Z, Fouda MM, Ebaid H, Hebeish A. Antidiabetic assessment; in vivo study of gold and core-shell silver-gold nanoparticles on streptozotocin-induced diabetic rats. Biomed Pharmacother. 2016; 83:865-75.

25. SharmaA.K., Ahmedl., TadayyonM., PoneryA.S., AloamakaP., AbsoodG. andPallotD.J.The beneficial effects of Momordicacharantia fruit juice on streptozotocin induced diabetes and hypertension in rats, Int. J. Diabetes 4 (1996) 29-38.

26. Shaw JE, Sicree RA, Zimmet PZ. Global estimates of the prevalence of diabetes for 2010 and 2030. Diabetes Res ClinPract. 2010;87(1):4-14.
27. Stumvoll M, Goldstein BJ, van Haeften TW. Type 2 diabetes: principles of pathogenesis and therapy. The Lancet. 2005;365(9467):1333-46.

28. Tierney LM, Saint S, Whooley MA. Essentials of diagnosis \& treatment, McGraw-Hill Medical Publishing. 2002.

29. WelihindaJ., ArvidsonG., GylfeE., HellmanB. andKarlssonE. The insulin releasing activity of the tropical plant Momordicacharantia, Acta Biol. Med. Germ. 41 (1982) 12291240.

30. YuanX.Q., GuX.H. and TangJ., Optimization of the production of Momordicacharantia L. Var. abbreviate Ser. protein hydrolysates with hypoglycemic effect using Alcalase, Food Chem. 111 (2008) 340-344.

31. ZengK., He Y.N., Yang D., Cao J.Q., Xia X.C., Zhang S.J. and $\mathrm{Bi}$ X.L. New compounds from acid hydrolyzed products of the fruits of Momordicacharantia L. and their inhibitory activity against protein tyrosine phosphatas 1B, Eur. J. Med. Chem. 81 (2014) 176-180.

32. ZhangL.J., LiawC.C., HsiaoP.C., HuangH.C., LinM.J., LinZ.H., HsuF.L. and KuoY.H.Cucurbitane-type glycosides from the fruits of Momordicacharantia and their hypoglycaemic and cytotoxic activities, J. Funct. Foods 6 (2014) 564-574. 